\title{
Introduction: Science in Policy Making
}

\section{Sabine Weiland, Vivien Weiss, and John Turnpenny}

Ecological challenges are becoming more and more complex, as are their effects on nature and society and the actions to address them. Calls for a more sustainable development to address these challenges and to mitigate possible negative future impacts are not unproblematic, particularly due to the complexity, uncertainty, and long-term nature of possible consequences (Newig et al. 2008). Knowledge about the various impacts-be they ecological, economic, or socialpolicies might have is therefore pivotal. But the relationship between such knowledge and the myriad ways it may be used is particularly challenging. The example of policy impact assessment systems is a case in point. Recent years have seen an institutionalization of such systems for evaluating consequences of regulatory activities across the Organisation for Economic Co-operation and Development (OECD 2008) and the European Union (CEC 2002). It is argued that, by utilizing scientific and other evidence, impact assessment has the potential to deliver more sustainable policies and to address large-scale global challenges.

In practice, however, the impact of policy assessments on actual decision making is rather different from what some expected (EVIA 2008). Direct impact of scientific knowledge on political decisions appears to occur only in a minority of cases. In many cases, research has a much more indirect and less predictable impact on policy through longer-term learning (Hertin, Turnpenny, et al. 2009). The lack of impact of scientific knowledge is seen by some as a missed opportunity for sustainable policy making, and is symptomatic of a large and deep gap between the two communities of scientists and policy makers.

\section{From Evidence to Policy}

It is not self-evident if and how scientific evidence and "high-quality" assessments necessarily translate into "better" policies. Rationalist expectations that assessments produce evidence for the best policy op- 
tions, which are then transferred into practice, appear somewhat naive. However, expectations of policy assessment's utility largely draw on a linear understanding of knowledge flow from science to the policyand decision-making arena; that is, science advice precedes and compels political decisions. This model rests on assumptions of objectivity and neutrality of scientific knowledge, and on science's autonomy from politics and hence from human values (Pielke 2007: 12). Post-positivist critiques of these forms of policy assessment, in contrast, stress the relativity of knowledge and the political nature of policy formation, thereby focusing on other factors, such as interests and power positions, rather than evidence (e.g., Owens et al. 2004; Sanderson 2004; Hertin, Jacob, et al. 2009). They argue that considerations of how scientific evidence is used in decision making, and of the role users of scientific knowledge have in its production, are vital for understanding the efficacy of science in decision making. This is all the more true in cases when science is unable to converge upon a solution, or the relevant problem is unstructured such that proponents cannot even agree on problem framings-so-called trans-scientific issues (Turnhout et al. 2007). In such settings, it is obvious that science's role may be instead to inform debate and critical reflection. This is, however, not to suggest that both research and practice should shift from a linear, rational model to deliberative and inclusive approaches; rather, they should coexist. Owens and colleagues (2004) highlighted the complementarities between the two models. Technically oriented assessments may, intendedly or as a side effect, create opportunities for policy deliberation of a more rationalist kind or conceptual learning that involves fundamental reframing of issues (Hertin, Turnpenny, et al. 2009).

\section{Science and Politics}

The policy studies literature on the relation between science and politics has a counterpart in science studies. Here as well, a variety of approaches exist that conceptualize the nexus between (natural) sciences and politics. One question is what actually constitutes "science", both in practice and epistemology. Whereas basic science in the Newtonian sense is seen to rest upon a search for universal knowledge free from political and societal influence-Merton's "ethos of science" (Merton 1973)_applied science places scientific results in the service of society, or sometimes industry, and hence is more con- 
cerned with the use of its findings. Various notions, such as "mandated science" (Salter 1988) and "regulatory science" (Jasanoff 1990), refer to a research that is targeted at policy makers and regulators, rather than scientific peers. In this context, a form of knowledge production ("Mode 2") is concerned with policy problems characterized by a high degree of uncertainty, complexity, and the need to transcend the traditional boundaries of science, resulting in the necessity of involving nonscientific forms of knowledge to create "socially robust" knowledge (Gibbons et al. 1994; Nowotny et al. 2001).

Science studies also deals with the interaction between science and politics. The concept of "coproduction of knowledge" holds that science and politics act together in knowledge production. Neither science nor politics can claim dominance in this process; they are in fact mutually dependent (Jasanoff 2004; Lemos and Morehouse 2005). "Boundary work" is a concept expressing how scientists maintain the boundary of their community and hence the cognitive authority of their work (Gieryn 1995). Originally referring to the relationship between science and nonscience, the concept of boundary work has since then been applied to the interface between science and politics (Guston 2001) and, more broadly, to organizations that mediate between knowledge and action (Cash et al. 2002). More recently, the concept of "transdisciplinarity" has been used to conceptualize the interface between science and society. Transdisciplinarity is often used as a synonym for research in the context of real-world problems characterized by a participatory and integrative process of knowledge production, and thus as capable of bridging the gap between science and politics/society (Hirsch Hadorn et al. 2008). Furthermore, a number of approaches deal on a more practical level with linkages between science and politics, such as through intermediate actors or institutions, knowledge brokers, and various forms of facilitation (e.g., Michaels 2009; Sheate and Rosário Partidário 2010).

\section{Understanding Scientific Evidence in Policy Making for Sustainable Development}

Against this background, this special symposium explores how the construction and utilization of scientific knowledge in policy making and its impact in the policy process itself can be better understood. As indicated above, there already exist a large number of concepts to theorize the science-policy interface and interaction. This symposium 
addresses how science and politics interact in practice, especially in the field of sustainable development. The aim is to move beyond apolitical, one-directional knowledge transfer models that still inform much of the debate on the utilization of science. At the same time, the persistence of these linear models is remarkable and in need of explanation.

The special symposium assembles empirical and conceptual contributions that make use of the above mentioned and other approaches to science-politics-policy interaction that shed light on the issue of evidence and knowledge construction and its use in policy making. Special attention is paid to the role of "nature" in this interaction-as hard natural science, as a solid boundary to protect science's authoritative claims, in relation to the natural core of socioecological systems, and so on.

The contribution of Jost Wübbeke, "The Science-Politics of Climate Change in China," shows that climate change is neither a purely scientific nor a solely political issue. Rather, science and politics together determine how climate change is understood and acted upon. His analysis of climate models and emission graphs from Chinese science reveals how these scientific inscriptions contain and coproduce political values and objectives of Chinese politics.

Karin M. Gustafsson and Rolf Lidskog study the IUCN Red List of threatened species, which is set up to counteract biodiversity loss. They analyze the construction of the Red List categories and criteria, and how these are used to construct red lists at global and national levels. These processes involve many different actors from science and politics and hence involve different forms of boundary work. The authors argue that the Red List is best understood as a boundary object in which the credibility of scientific assessment and a specific policy are mutually strengthened.

The article by Heli Saarikoski and Kaisa Raitio also focuses on the issue of coproduction. It demonstrates the interconnectedness of science and politics through a case study of old-growth forest conflict in Finnish Upper Lapland. "Traditional science" has failed to settle the long-standing conflict between state forestry and traditional Sámi reindeer herding. Therefore, the authors discuss the potential of more inclusive science, through "joint fact-finding", to create a policy-relevant and robust knowledge basis for future forest policy.

In his contribution, "Modes of Constructing Evidence: Sustainable Development as Social Experimentation," Stefan Böschen addresses the 
knowledge conflicts related to sustainable development. Based on the assumption of differing modes of evidence creation within "epistemic" and "practice" communities, he interprets knowledge production as a process of social experimentation. Using the cases of chemicals regulation and climate change politics as examples, he shows the ways in which "formative publics" organize the contexts for this experimentation and impact on the results. His findings emphasize the need to elaborate processes and structures for processing knowledge for sustainable development.

The final contribution, by Paul D. Hirsch and Valerie A. Luzadis, "Scientific Concepts and Their Policy Affordances," deals with the development of policy-relevant knowledge. The authors propose to better link up different sciences as well as science and politics: first, a focus on compatibility, instead of competition, may promote more effective interdisciplinary scientific collaborations; second, attention to the affordances of knowledge with respect to the policy process may inform the development of policy options in a more robust way. Like Böschen, the authors emphasize the importance of the political context in which scientific knowledge affords policy action.

Overall, we can learn from these rich contributions to better understand science-policy interaction-and to eventually better conduct policy assessments that are supportive of sustainable development.

\section{Acknowledgment}

The editors would like to thank the LIAISE (Linking Impact Assessment Instruments to Sustainability Expertise) Network of Excellence (NoE FP7-ENV-2009-1, project number: 243826) for helping to fund this Special Symposium.

Sabine Weiland is a senior researcher at the Environmental Policy Research Centre (FFU) at the Freie Universität Berlin. She is currently working on the project LIAISE (Linking Impact Assessment Instruments to Sustainability Expertise), an EU FP7-Network of Excellence. In addition, she is engaged in various other research projects in the field of policy assessment, sciencepolicy interface, and sustainability governance. Sabine holds a PhD in social sciences from the University of Göttingen, Germany. Currently, she is working on her habilitation on reflexive governance. Address: Environmental Policy Research Centre, Freie Universität Berlin, Ihnestr. 22, 14195 Berlin, Germany. Email: sabine.weiland@fu-berlin.de. 
Vivien Weiss is researcher at Helmholtz-Centre for Environmental Research-UFZ in Leipzig, Germany. Her research focuses on different types of research organization and how collaboration in transdisciplinary forms of research enterprises takes place. Her PhD thesis deals with a joint research project in the field of contaminated land and shows how the research team came up with a tool ready to be used by stakeholders for the integrative management of brownfield revitalization processes. Her general research interest is the relation between science, policy and society, production of knowledge, and environmental sociology. Address: Helmholtz Centre for Environmental Research GmbH_-UFZ, Department of Urban and Environmental Sociology, Permoserstr.15, 04318 Leipzig, Germany. Email: vivien.weiss@ufz.de.

John Turnpenny is a senior lecturer in public policy and public management in the School of Political, Social and International Studies at the University of East Anglia, UK. His research focuses, broadly, on the relationship between evidence and public policy making, and more specifically on policy analysis tools, construction and deployment of scientific evidence, postnormal science, and the boundary work of different policy actors. He takes a multidisciplinary approach to studying the politics of policy making, and is particularly interested in environment, sustainable development, and climate change-related policy. Address: Tyndall Centre for Climate Change Research School of Environmental Sciences, University of East Anglia, Norwich, NR4 7TJ, UK. Email: j.turnpenny@uea.ac.uk.

\section{References}

Cash, David, William Clark, Frank Alcock, Nancy Dickson, Noelle Eckley, and Jill Jäger. 2002. Salience, Credibility, Legitimacy and Boundaries: Linking Research, Assessment and Decisions Making. Discussion Paper RWP02_046. Cambridge, MA: John F. Kennedy School of Government.

Commission of the European Communities (CEC). 2002. Communication from the Commission on Impact Assessment. COM(2002) 276 final. Brussels: Report of the European Commission.

EVIA-Evaluating Integrated Impact Assessments. 2008. "Case Studies on Implementation of IA at the Level of EU MS." Berlin: Report from the EVIA Project, Funded Under EU FP 6.

Gibbons, Michael, Camille Limoges, Helga Nowotny, Simon Schwartzman, Peter Scott, and Martin Trow. 1994. The New Production of Knowledge: The Dynamics of Science and Research in Contemporary Societies. London: Sage.

Gieryn, Thomas F. 1995. "Boundaries of Science." In Handbook of Science and Technology Studies, ed. Sheila Jasanoff, pp. 393-443. Thousand Oaks, CA: Sage.

Guston, David H. 2001. "Boundary Organizations in Environmental Policy and Science: An Introduction." Science, Technology \& Human Values 26 (4): 399-408.

Hertin, Julia, Klaus Jacob, Udo Pesch, and Carolina Pacchi. 2009. "The Production and Use of Knowledge in Regulatory Impact Assessment: An Empirical Analysis." Forest Policy \& Economics 11 (5-6): 413-421. 
Hertin, Julia, John Turnpenny, Andrew Jordan, Mans Nilsson, Duncan Russel, and Björn Nykvist. 2009. "Rationalising the Policy Mess? Ex Ante Assessment and the Utilisation of Knowledge in the Policy Process." Environment and Planning A 41 (5): 1185-1200.

Hirsch Hadorn, Gertrude, Holger Hoffmann-Riem, Susette Biber-Klemm, Walter Grossenbacher, Dominique Joye, Christian Pohl, Urs Wiesmann, and Elisabeth Zemp. 2008. "The Emergence of Transdisciplinarity as a Form of Research." In Handbook of Transdisciplinary Research, ed. Gertrude Hirsch Hadorn, Holger Hoffmann-Riem, Susette Biber-Klemm, Walter Grossenbacher, Dominique Joye, Christian Pohl, Urs Wiesmann, and Elisabeth Zemp, pp. 19-39. Dordrecht, the Netherlands: Springer.

Jasanoff, Sheila. 1990. The Fifth Branch: Science Advisors as Policymakers. Cambridge, MA: Harvard University Press.

Jasanoff, Sheila. 2004. States of Knowledge: The Co-production of Science and Social Order. London: Routledge.

Lemos, Maria Carmen, and Barbara J. Morehouse. 2005. "The Co-production of Science and Policy in Integrated climate assessments." Global Environmental Change 15 (1): 57-68.

Merton, Robert K. 1973. The Sociology of Science: Theoretical and Empirical Investigations. Chicago: University of Chicago Press.

Michaels, Sarah. 2009. "Matching Knowledge Brokering Strategies to Environmental Policy Problems and Settings." Environmental Science \& Policy 12 (7): 994-1011.

Newig, Jens, Jan-Peter Voss, and Jochen Monstadt. 2008. Governance for Sustainable Development: Coping with Ambivalence, Uncertainty and Distributed Power. London: Routledge.

Nowotny, Helga, Peter Scott, and Michael Gibbons. 2001. Re-thinking Science: Knowledge and the Public in an Age of Uncertainty. Cambridge: Policy Press.

Organisation for Economic Co-operation and Development (OECD). 2008. Building an Institutional Framework for Regulatory Impact Assessment: Guidance for Policy-Makers. Paris: OECD Publications.

Owens, Susan, Tim Rayner, and Olivia Bina. 2004. "New Agendas for Appraisal: Reflections on Theory, Practice, and Research." Environment and Planning A 36 (11): 1943-1959.

Pielke, Roger A., Jr. 2007. The Honest Broker: Making Sense of Science in Policy and Politics. Cambridge: Cambridge University Press.

Salter, Liora. 1988. Mandated Science: Science and Scientists in the Making of Standards. Dordrecht, the Netherlands: Kluwer.

Sanderson, Ian. 2004. "Getting Evidence into Practice: Perspectives on Rationality." Evaluation 10 (3): 366-379.

Sheate, William R., and Maria Rosário Partidário. 2010. "Strategic Approaches and Assessment Techniques: Potential for Knowledge Brokerage towards Sustainability." Environmental Impact Assessment Review 30 (4): 278-288.

Turnhout, Esther, Matthijs Hisschemöller, and Herman Eijsackers. 2007. "Ecological Indicators: Between the Two Fires of Science and Policy." Ecological Indicators 7 (2): 215-228. 